This item was submitted to Loughborough's Research Repository by the author.

Items in Figshare are protected by copyright, with all rights reserved, unless otherwise indicated.

\title{
Trauma, emotions and memory in world politics: The case of the European Union's foreign policy in the Middle East conflict
}

\section{PLEASE CITE THE PUBLISHED VERSION}

https://doi.org/10.1111/pops.12459

\section{PUBLISHER}

(c) International Society of Political Pyschology. Published by Wiley.

\section{VERSION}

AM (Accepted Manuscript)

\section{PUBLISHER STATEMENT}

This work is made available according to the conditions of the Creative Commons Attribution-NonCommercialNoDerivatives 4.0 International (CC BY-NC-ND 4.0) licence. Full details of this licence are available at: https://creativecommons.org/licenses/by-nc-nd/4.0/

\section{LICENCE}

CC BY-NC-ND 4.0

\section{REPOSITORY RECORD}

Pace, Michelle, and Ali Bilgic. 2017. "Trauma, Emotions and Memory in World Politics: The Case of the European Union's Foreign Policy in the Middle East Conflict”. figshare. https://hdl.handle.net/2134/26931. 


\title{
Trauma, Emotions and Memory in World Politics: \\ The Case of the European Union's Foreign Policy \\ in the Middle East Conflict
}

\author{
Michelle Pace and Ali Bilgic
}

\section{Accepted for Publication in Political Psychology (September 2017)}

\section{Introduction}

Recent methodological innovations in the discipline of International Relations (IR),have produced plausible and practical ways to study emotions (Bleiker and Hutchison, 2008; Hutchison, 2016: 160; Mercer, 1997; Sasley, 2011; Schilling, 2015). Following these openings, this article examines how emotions impact on the foreign policy practices of agents, such as institutions, in world politics. In particular, the link between emotions and the ways in which past traumatic experiences are remembered is explored with reference to the EU's identity and agency vis-à-vis the Israeli-Palestinian conflict. It will be argued that the EU representatives' emotional performances in relation to the Palestinian-Israeli conflict can be understood as a technique of expressing what the EU stands for to others against the backdrop of a shared traumatic history. In other words, the 'memory of trauma', which refers to past traumatic experiences that are institutionalised and instrumentalised in the process of identity construction in the present, is translated into a foreign policy practice through emotional performances of EU representatives.

The analysis starts with a conceptual discussion about how emotions can be studied in global politics in the context of traumatic pasts. We argue that emotions - as conscious representations of feelings by individuals - construct collective identities and shape the agency of institutions by enacting the memory of trauma. In particular, we draw upon Hutchison (2016) and Bially Mattern's (2011) analytical frameworks, which provide us with crucial pointers on what emotions are, how they affect politics, and specifically, world politics. We complement our investigation with Sara Ahmed's (2004) work which sheds light on how emotions are felt, enacted, performed, and projected depending on historically constructed political contexts. In the second section, we examine the EU representatives' emotional performances in relation to the conflict.

Our empirical work is based on ethnographic research carried out by one of the authors over a number of years in Israel, the occupied Palestinian territories and Brussels (at the European External Action Service/Council, the Commission and the 
European Parliament). The time period of this ethnographic research spans over thirteen years: from January 2004 up to the most recent field trip conducted during October 2016. (All field trips by the said author have been connected to specific research grant projects funded by the EU, the ESRC, the Heinrich Böll Stiftung and the Carlsberg foundation). Working as a field researcher in a highly conflictual and polarized setting entails a number of ethical and emotional challenges. Most interviews, focus groups (maximum of 6 participants per group) and observations were held in English amongst Palestinians, Israelis and EU officials including EU member states officials on the ground in the conflict area. Throughout the said research, care was taken to ensure a balanced representation of subjects in relation to gender, class, educational background, etc. Focus groups were held with youth, academic, business and NGO groups. Interviews were mainly held with officials/elitegroups. All these qualitative methods took place with the fully informed consent of the research subjects. In such highly sensitive research the anonymity of those interviewed/observed and the confidentiality of the data gathered were ensured to the extent possible.

Before the discussions that follow below, three clarifications are in order. First, as emotions are inextricably linked to individuals, by the EU, we mean the EU's official representatives who embody what the EU stands for and how it is represented in its external affairs. In the EU's foreign policy literature, the impact of emotions on the EU's foreign policy actorness, defined as 'the capacity to behave actively and deliberately in relation to other actors in the international system' (Sjöstedt 1977: 16) and agency in terms of affecting structural processes and relations through its representatives remain, to say the least, severely understudied. This article aims to fill this gap by nuancing the role of emotions in the EU's foreign policy as well as how these emotions impact on the EU's international identity and agency in relation to one of the most emotionally loaded, prolonged conflicts by focusing on the narratives of EU representatives in the Israel-Palestinian context. Secondly, we take trauma not at the individual level as an unconscious experience but at a collective level, which is always public and instrumental to a policy goal, and a matter of public discourse (Becker: 2014: 63). The focus of our discussions is not a particular traumatic event experienced by an EU collective of officials or representatives but rather how the traumatic past is remembered and enacted politically and publicly. Thirdly, we acknowledge that not all EU member states may necessarily share the same national mythologies about these events (for more on the emotional appeal of European myths see Lynggard, 2016). Yet, what brings the EU collective together in this context are the shared experiences of past traumatic processes and what we want to shed light on is the way in which these emotions are performed.

\section{Emotional Performances in International Relations: Enacting the memory of trauma}

Constructivist and poststructuralist/postmodernist turns in IR enabled the study of memory in world politics. World Wars and the holocaust (Zehfuss, 2007), the 
Vietnam War and 9/11 (Edkins, 2003), the fragmentation of Yugoslavia and the subsequent wars (Ray, 2006), the apartheid regime in South Africa and truth and reconciliation committees established - in the course of 'healing' and 'dealing with the past' (Meskell, 2006), and through the use of memory in foreign policy practices (Becker, 2014; Sasley, 2014) - an analytically scrutinized space within the IR domain.

While the studies of memory reveal the political, highly selective, and productive role of the past in the reproduction of the present and the future, a particular mnemonic moment has attracted overwhelming attention from IR scholars: trauma.Like memory, trauma is a 'messy' concept. It is highly individualistic and evokes feelings of helplessness, pain and confusion - at the same time as it is collective (Herman, 2015). In addition, trauma often goes beyond the limits of language: feelings that are experienced because of trauma cannot be easily expressed within the existing language systems (Edkins, 2003; Hutchison, 2016). That is why, as will be shown below, 'speechlessness' is a common expression in the face of a traumatic event.Yet, trauma is still communicated through individuals' own attempts and struggles to express their own traumatic past. However, the present analysis focuses on how a traumatic past is remembered today as a political project, as studies of trauma in IR have powerfully shown. In this way, traumas, or 'memories of trauma' (Edkins, 2006: 100) have become part of culture. Fierke (2006: 121) explains as follows:

The literal experience of trauma may be beyond representation, but in the imitation or acting out of the traumatic event, the victim reproduces the linguistic boundaries of the past experience. Trauma is consequently part of a cultural package involving a range of speech acts, patterns of relationships and assumptions.

Then she argues that trauma of the past can provide the basis for social practices based on habitual memory (125). Memorials, monuments, remembrance days, and museums are built as part of a narrative that links a traumatic past with the present (Edkins 2003 and 2006; Feuchtwang, 2006). In other words, 'chosen' memories of trauma can be socially institutionalised and relived and, therefore, become part of individual and collective identities (Kinvall, 2002).

The memory-trauma nexus poses a number of analytical and methodological challenges. As both memory and trauma are highly based on individual experiences and practices while IR studies focus on the social and collective level in order to examine the politics of memory and trauma (Fierke, 2006; Meskell, 2006), the fundamental challenge is how to shift from the individual to the communal, social, and cultural level. Scholars of memory and trauma have generally addressed this challenge in two ways. First, adopting either the Lacanian psychoanalytical (e.g. Edkins, 2006) or constructivist (e.g. Becker, 2014) approach to identity, most of them reject the hypothetical separation between individual and collective identities but assume their mutually constitutive character. The second way stems from the 
methodological openings that poststructuralist/postmodernist studies have enabled. Since individual and collective identities are mutually constructed in discursive contexts, the linguistic (narratives) and non-linguistic materials (monuments, memorials, remembrance days) that produce this context are studied as the ways in which memory and trauma are collectivised (e.g. Bleiker and Huang, 2006).

In analysing foreign policy practices, narratives are particularly useful. Narratives are 'primary ways by which we make sense of the world aroundus, produce meanings, articulate intentions, and legitimise actions' (Wibben, 2010: 2). In memory of trauma studies, they are conceptualised as stories that we tell about ourselves and others by articulating meaning of the past for the present and future. They provide a thread along which individual and collective identities are (re)constructed. That is why, in their study of states' articulations of narratives of trauma, Innes and Steele (2014: 17) call these stories '(auto)biographical identity narratives', which are uttered by state representatives repeatedly and consistently. Narratives are institutionalised stories that articulate what the actor (in our case, the EU) is and what types of actions the actor performs.

While we agree with and take the novelties the studies of memory and trauma have introduced on board, we argue that one fundamental dynamic, emotions, that also oscillates between individual and social levels by collapsing them into each other is neglected (exception, Hutchison, 2016). The role of emotions, to name a few, anger, frustration, hate, fear, love, compassion, and pride, are almost always acknowledged in the works on memory and trauma in IR (e.g. Ray, 2006). After all, as Bell (2006: 2) suggests, social memory is based on 'affective bonds' between individuals; as Alexander (2004: 1) argues, 'traumas occur when individuals and groups feel that they have been subjected to a horrendous event'. Collective identities are even called 'emotional communities' (Resende and Budryte, 2014: 8). The role of emotions in remembering a traumatic past, which, in this article, we call 'memory of trauma', cannot be omitted or reduced to simple intervening variables between memory and collective identity. Emotional performances in the narratives of policymakers do the work of constructing institutional identity in the context of a traumatic past. This leads us to reflect on the following: In considering what emotions do politically in remembering a traumatic past and how they carry the particular chosen past into the present, we ask how is the memory of trauma translated into practice, more specifically, foreign policy practice, and in what ways does memory of trauma shape international institutions' identity and agency? We argue that emotions offer answers to these questions and these answers can also help address the analytical and methodological challenges that memory and trauma studies face.

Crawford (2000), Mercer (2006 and 2010), and Bleiker and Hutchison (2008) were among the first IR scholars who conceptualized emotions. Others followed suit (Moisi 2007 and 2010; Pain 2009; Sasley 2011; Bially Mattern, 2011). ${ }^{[1]}$ As there are multiple ways of studying emotions and emotional processes in IR, a more concise conceptual framework is needed in order to analyse emotions in relation to 
institutions' identityand agency in global politics. An emotion is a conscious expression or display of a feeling in a historically constructed discursive context (Hutchison, 2016: 16). Although they are felt by individuals, 'feelings are formed and structured within particular social and cultural environments' (Hutchison and Bleiker, 2014: 504). Discursive context (in our case, the memory of trauma) with its linguistic and non-linguistic communication systems is the sphere where feelings are consciously expressed as emotions. Narratives of EU practitioners will be the main research materials in the second section.

Emotions cannot be privatised: they are not possessions of individuals (Saeidi and Turcotte, 2011: 694). Rather, emotions are constituted by discourse, which refers to norms and values of significance that attribute meaning and value. Discourse is generated through representations (i.e. habits, customs, languages, practices) which are also used to express and communicate feelings (Hutchison, 2016: 139-140). Therefore, when a feeling is 'represented' (i.e. performed) linguistically or nonlinguistically and articulated as an emotion, this performance is derived from a specific discursive context that is, in turn, reconstructed through the emotional performance. Through this triangle of emotion-representation-discourse, the actor's agency, meaning, what it can or cannot do, is shaped (Fierke, 2009: 171). As opposed to affect and feeling, the concept of emotion takes the analytical scope from the individual level towards discursive structures that are historically and politically constructed. As the object of the present study is an institution, the $\mathrm{EU}$, we focus on the emotional performances of the EU as embodied through its representatives. Institutions in politics, and global politics for that matter, are also imbued with discourses about what that institution is and its abilities. Therefore, how the EU's representatives express their emotions is derived from the EU's institutional discursive context and signal what the EU is and what it can potentially become.

Thus, emotions are expressions of 'the self' compared to others in a historically and politically constructed discursive context; they cannot be easily situated in the frameworks that prioritize agency or structure and biology or culture. Rather, they are unique experiences that are practiced (Bially Mattern, 2011: 66 and 69). Emotions as performances or practices are a technique: 'how one is experiencing their own existence in the world at a given moment' in relation to others and objects (2011: 73, see also Hutchison, 2016). Here, Mattern makes an important point for the key focus of our analysis: emotions as practices are not given and external to agents and structures, but are a moment of 'being' that does not only create agency, but also affects social orders (structures). In other words, emotions as practices are not independent ontologically from the agent or structure, but are constitutive of them (2011: 74).

Bially Mattern's analytical framework provides crucial notions about what emotions can be, how they do/explain/affect politics, in particular, world politics. Contrary to approaches that underestimate agency (physiological), overestimate agency (cognitive), or overestimate structure (social, cultural), the practice approach thus 
reveals how emotions in their own capacity are constitutive both of agency and structure. As a result, emotions in their own right can be studied and their implications can be revealed without confusingthem with their possible biological or social sources. Furthermore, emotions do not just happen, but they are 'learned'. As one of the techniques through which one makes oneself present to others, emotions are experienced, recognized, and understood as a result of the continual interaction of the being with its environment (2011: 77). Finally, emotions have the potential to shape both agency and structures. Individuals are not machines that repeat 'selfexpressive routines', but they exceed routines (2011: 74). What type of feelings are performed as emotions can be an individual's choice. This issue will be clarified below through our specific case focus.

EU representatives' emotional performances in relation to the Palestinian-Israeli conflict can be understood as a technique of expressing themselves to (internal and external) others in the EU's institutional 'habitual memory'. These performances can be identified as an important, albeit not exclusive, constitutive dimension of EU officials' coping mechanisms in relation to this conflict on a day-to-day basis. EU representatives' emotional performances are certainly learned through the experiences of former EU officials with other internal and external others. "What I have learned from my predecessor is that our task in this intractable conflict is always to try and make the conflict parties see reason ... not an easy feat," (interview with former special adviser to Marc Otte, EU Special Representative, Middle East Peace Process, Brussels, April 2009). Thus, emotional performances are learned within the EU's social structure, referring to socialized norms or tendencies that guide behavior and thinking. However, there are occasions when we can observe a change in the way EU representatives perform their emotions (see Hutchinson 2016) given the contingent social structure of the conflict. "We are absolutely appalled and outraged at the Israeli government for its summer (2014) bloody 50-day military attack on the Gaza Strip which resulted in 2145 fatalities, including 581 children" (interview with an EU official, Jerusalem, October 2014). Therefore, the practice theory of emotions enables an analysis that goes beyond showing emotions in communications and representations (i.e. Bleiker and Hutchison, 2008) or how they are instrumentalized in political projects (Fattah and Fierke, 2009). Rather, a practice approach reveals how the foreign policy of the EU (as embodied through the agency of its representatives) is shaped through and influenced by emotional performances that can potentially challenge what the EU represents at particular junctures, as well as the social order in which EU officials interact with others (in our case, Israelis and Palestinians). However, in order to engage in this discussion, it is important to bring the 'identity' question into the analysis, as suggested by Bially Mattern (2011:79). If emotion is a performance of 'being', this is inextricably related to what the self is, can be, and projects itself to be.

Hence a second conceptual dimension of our framework concerns the role of emotions in the construction of identities. If emotions are the ways that the self 
expresses and communicates its feelings in a historical and political discursive context, emotions are inextricably relational. Sara Ahmed's influential work on emotions in politics can be helpful in discussing the emo-tion/identity nexus. Ahmed's main question concerns what emotions do politically, and how. This question is relevant and related to Bially Mattern's problematique, but with less emphasis on ontologies of emotions and the ostensible dichotomy between agency and structure. Instead, Ahmed's focus is on identities and power relations in which emotions are performed. According to Ahmed, 'emotions are not simply something 'l' or 'we' have. Rather, it is through emotions, or how we respond to objects and others, that surfaces or boundaries are made. The 'l'and 'we' are shaped by, and even take the shape of, contact with others' (Ahmed, 2004: 10). A subject feels something in relation to another and this feeling brings about affective reactions. These feelings (and affects) are hardly arbitrary; they are derived from experiences of history of previous encounters, or rather, from discursive representations of this political history. A subject expresses and communicates, or enacts, the feeling either through linguistic or non-linguistic practices (Ahmed: 2004, 87-88). Through performing an emotion, a subject produces 'the self' as the subject who performs emotion and 'the other' as the object of the emotional performance. Therefore, emotional practices become constitutive dynamics of identities and subjectivities (Hutchison, 2016: 103). In conclusion, borders are thus (re)drawn between the self and the other, and the subject and object through emotional performances.

When EU representatives express or represent their emotions through communicative practices, their emotional performance not only constructs what the EU stands for as the self and its agency, but these practices are constitutive of the structural dynamics operating within EU institutions and the processes through which foreign policy is formulated. This leads us to our final conceptual point about emotions in global politics. Emotions can be institutionalized (Crawford, 2014). This means that emotions that are discursively expressed by individuals underline the way in which institutions are constructed, which in turn engenders a structural effect through which emotions can be experienced and how they become 'represented'. Unlike an approach that strategizes and instrumentalizes 'emotions' in pursuant of the interests of a political institution such as a state, and therefore, ontologically separating 'the self' as the actor and 'emotions' as its tools (Hall, 2015), the institutionalization of emotions as defined by Crawford points at a process where emotions become constitutive of the construction of a political institution. In this case, emotions do not simply reflect institutions as structures, but institutions themselves become expressions of emotions, which has implications for what type of agency that institution comes to represent. When emotions are institutionalized, they become intrinsic to discourses of individuals representing that same institution, who 'learn' how to perform an emotion in the given institutional context.

However, it must be noted that multiple emotions - some of which can be conflictive with each other - can be institutionalized in the same actor's political practices. This 
relates to Bially Mattern's aforementioned point about how we can observe change in individuals' emotional performances. Representatives of political institutions sometimes have choices to make about how to express and communicate their feelings within the institutional settings at hand. In other words, as Hutchison (2016: 146) argues, representations also carry a potential to challenge identity and agency. EU representatives' emotional performances can thus at times express a wish for a different kind of EU identity and agency by acting out their emotions differently.

If emotions are contextual, it begs an analytical question about in what context emotions are expressed in this specific case study. A way to address this challenge surfaced during the empirical research: all sides of the case (EU, Israeli, andoPt officials) are bound by a common thread, that is, memory of trauma.

As the studies on memory show (e.g. Bell, 2006), memory creates affective bonds between individuals through emotional appeals (proud about the past, injustice, guilt, sense of belonging etc.). Collective identity is, therefore, constructed based on collective memory, pieces from the past that are chosen. These affective bonds are partly produced through narratives, which are constructed by individuals, institutionalised in time and constitutive of the group's identity. Using Fierke's terminology, narratives reflect and shape 'habitual memory' of the collectivity and are instrumental to formulate foreign policy identity and agency for international actors. Becker (2014: 60) argues that narratives create and reinforce a certain image of the actor and its foreign policy is formulated and communicated in line with this image. We argue that a fundamental way to construct this identity is emotional performances of members of institutions.

When an individual as a member of a community performs an emotion discursively, s/he invokes the narrative (in our case, the narrative about the memory of trauma) and enacts and reconstructs the community's collective identity. Narratives with emotional underpinnings not only target 'the self' but also express the group's being to an/ 'the other' and define the scope of its agency. Through institutionalised narratives, emotions become the expression and a communication method of the collective self with the outside world. When individuals (EU representatives) perform an emotion in relation to the Middle East conflict, this performance stems from the institutionalised narrative structure within the EU's foreign policy-making. We argue that this narrative structure is constitutive of the memory of trauma, not only of Europe's but also others' (the holocaust and nakba) memories of traumatic past. Trauma is enacted through emotional performances of individuals (EU representatives) who articulate institutionalised narratives. As a result, the EU's foreign policy identity (and agency) is reproduced through emotional performances of its representatives.

In this analysis, memory of trauma and emotions appear in two fundamental ways. First, the feelings of compassion and sympathy towards the victims of trauma are 
institutionalized in the EU's foreign policy agency vis-à-vis the Israeli-Palestinian conflict. In particular, children, especially those in refugee camps, are often identified as victims of trauma. In this way, EU's representatives construct an identity of the EU in relation to the outside world by actively communicating these feelings, and therefore, engaging in emotional performativity. However, it must be noted that EU representatives' emotional performances are linked to a deeper historical context: memory of past traumas. The second way trauma affects the EU's foreign policy identity and agency relates to the respective memories of past traumatic experiences of EU, Israeli and Palestinian representatives, which are interconnected. The latter two groups frequently refer to their own traumatic experiences, the holocaust and the "nakba" respectively, in their dealings with the EU. Mistrust towards the EU, victimhood, and injustice appear to be the main feelings associated with their respective traumatic pasts. The EU's own traumatic past, World War II, the holocaust and the ensuing "nakba", is often associated with feelings of guilt and shame, as the interview material will show below. When either Israelis or Palestiniansmake analogies between the EU's policy and the past (the holocaust or nakba), EU representatives often express 'shock'. EU representatives' emotional performances below express the EU's 'self' towards 'the Other' by redrawing the boundaries between the EU and Israel or Palestine. The EU is very often articulated as compassionate and sympathetic towards the parties, especially those who are identified as 'the most vulnerable groups', because of their respective traumatic experiences, but we also observe shifts in these emotional performances.

\section{The EU's identity and emotional performativity in the Israeli-Palestinian conflict}

In their work on the international identity of the EU, Manners and Whitman focus on the active and reflexive dimensions of the EU's attempts to assert its identity on the international scene (Manners and Whitman, 1998 and 2003). Building on their earlier 'premise that Europe, Western Europe, the European Union and its member states represent a set of varied but interrelated identities constructed and represented through different means and mechanisms' (Ibid. 1998: 236) they argue that the international identity of the EU is 'based on addition - the addition of identities, processes, communication and socio-political networks' (Manners and Whitman 2003: 400). We wish to add the role that emotional performativity of EU representatives plays in the EU's collective identity formation. In the case of the EU, the constitution of its very "being", its origins and foundations have been built on narratives / memory of a collective and overwhelming traumatic experience - the ruins and aftermath of the first and second World Wars (Bottici and Challand 2013; Kattago 2012). This past casts its shadow on the present of Europe (as represented through the EU and its political representatives) as an ugly reminder of the dark side of modernity (Kattago, 2012). Here a link emerges between Europe's past, the birth of Israel and the Palestinians' 'nakba' (meaning, catastrophe): all collectives of Europeans, Israelis and Palestinians have been through deeply traumatic 
experiences and ensuing memories and narratives thereof, with their respective subjective interpretations of said events.

The traumatic past influences how the EU frames the Israel-Palestine conflict. As Entman (2004) argues, framing is the process of selecting some aspects of a perceived reality and (making) them more salient in a communicating text, in such a way as to promote a particular narrative, problem definition, causal interpretation, moral evaluation and or treatment / recommendation of the item described. However, if there are emotional shifts, that is for instance less positive emotional leanings (as discursively uttered by EU representatives) towards for instance the Israeli government, which are at particular moments replaced by others, this is constitutive of an imagined new EU self and its agency, in addition to the social order in which it interacts with others. When Prime Minister Netanyahu condemned the EU's initiative to label certain goods produced beyond the Green Line as similar to what happened during the holocaust, Ambassador Lars Faaborg-Andersen, EU envoy to Israel, responded:

I have been shocked to hear claims of anti-Semitism and historic comparisons or analogies to the persecution of Jews in Germany in the 1930s and 40s ... In my view, this is a distortion of history and a belittlement of the crimes of the Nazis and of the memory of their victims ... The bond between Europe and Israel is unbreakable and indispensable and for the most part, our relations are consensual and thriving. But it is no secret that we do not agree on all points. Yet even where we do not agree it is important to keep a sense of proportion and not to confuse fact with fiction. (Quoted in Ahren, 2015, italics added)

In other words, the emotional self-expressions of EU representatives may at times change the image or representation of the EU's foreign policy and symbolize what these representatives wish the EU would aspire to become in a changing social order. In the quote above, Lars Faaborg Andersen is very clear in his wish to see the EU stand firm in terms of its principles of what is right and wrong: settlements are illegal according to international law and this is what the EU stands for - respect for international norms. What is crucial for the present analysis is the way this EU representative performs this emotion: he was 'shocked' because memory of the EU's traumatic past was re-articulated in a 'distorted' way (with the implication that Europeans have repeated the same practices of the traumatic past). Thus, this emotional performance not only re-constructs the EU's identity as markedly different from the past it emerged from, but also constructs its foreign policy as having normative law abiding agency.

For EU representatives, the memory of World War II has been a crucial phenomenon that affects the way they emotionally perform in regard to the Israeli-Palestinian conflict. Questions of criminality, guilt, and collaboration have intersected with history and politics on the local level to shape the way that wartime experience has been memorialized, reinterpreted, and used (Chirot et al, 2014). World War II continues to 
influence generations of EU officials, their attitudes and politics vis-à-vis Israel and the oPt on a very broad scale. During interviews in Brussels by one of the authors, a number of EU elites elaborated on the challenges they face in handling memories and reflections about guilt especially in the context of the holocaust and the creation of the Israeli Palestinian issue. These personal narratives suggest that when we reflect about the EU representatives' emotional performances in this case we need to take into account the war's legacy and the continuing impact of memory of trauma on EU elites. As one official put it:

The Second World War evokes powerful emotions and in relation to the holocaust and the creation of the Middle East conflict in particular, grief and humiliation, outrage, guilt, shame and pain. Such feelings have formed essential parts of national mythologies across EU member states. And such embedded emotions often leave us speechless in the face of atrocities that continue up to this day in Israel and Palestine ..." (interview held with an official from the Middle East section, European External Action Service, Brussels, $13^{\text {th }}$ June, 2011).

Although memories across EU member states may, as already stated above, not necessarily be similar and shared myths about these traumatic events, they do have an affect on the emotional performativity of diverse EU officials from the European Parliament, Council or Commission but particularly on EU representatives in Israel and the oPt. 'Speechlessness' may well be an effect of trauma although EU representatives often issue strong statements urging parties to the conflict to stop the violence and to return to the negotiating table. The author carrying out the fieldwork for this article also observed a difference in the emotional performativity (of these EU officials based on the ground) when speaking in an unofficial capacity:

The situation here (in the oPt) is truly a cause for alarm. Breaches of international law related to the Israeli military occupation take place on a regular basis and in a variety of ways, including frequent collective punishment, confiscation of land, exploitation of water resources, home demolitions, restrictions on the freedom of movement and goods, administrative detentions, and the harassment, psychological trauma and torture of Palestinian detainees and prisoners. The presence of Israel's military, the continual establishment of illegal Israeli settlements, and the separation barriers create a daily dangerous and inhumane environment for Palestinians in which children and women are particularly vulnerable. The significant increase in the detention of children and the recent law by the Israeli Parliament to lower the age of detainees is especially troubling," (interview with an official from the Office of the EU Representative in Jerusalem, October 2014, own emphasis).

Therefore not only history, but also the daily experience of living in the oPt, and the ways in which EU officials emotionally perform their experiences give academic observers different political categories that reflect the affect dimension in the EU's agency as represented by its elites (see also Demertzis, 2013). 
From thepart of Israelis, Newman and Yacobi (2008) have argued that the general critique stemming from Israel about the EU's agency in the Israel-Palestine issue continues to reflect deeply-rooted feelings of mistrust amongst the Israeli (Jewish) public vis-à-vis Europe and Europeans in general. These feelings have historical associations for most Israelis with experiences of persecution and holocaust. As Uri Avnery of Gush Shalom in Tel Aviv (quoted in Broadhead and Keown, 2007: 29 ) wrote:

The holocaust overshadows everything the Israeli people think and do. Our attitude is conditioned by the Holocaust. It conditions Israel to justify any means because compared with the Holocaust any bad things we do are negligible by comparison. It is a standard of comparison, which gives a kind of moral permit to do anything. In a way we are still victims of the Holocaust today but in a different way. It twists our outlook on things ... (Moreover), Israelis have a self-protective habit: when confronted with inconvenient truths, they evade its essence and deal with a secondary, unimportant aspect.

Therefore, the cycle of emotional performativity sets in: with Israeli or Palestinian rejection of 'inconvenient truths', we observe underlying emotions associated with their memory of collective traumas or what some have earlier termed 'sociopsychological barriers' that perpetuate the distorted and eroded interpretation of every event and every statement in the conflict from both sides (Ross and Ward, 1995; Bar-Tal and Halperin, 2011).

The ways in which Israelis and Palestinians relate to European countries show a deeply embedded relationship between the respective collective's identity and their emotional performativity thereof: Perceptions of Europe as 'anti-Semitic' continue to strive amongst the majority of the Israeli public and become strengthened through increasing 'anti-Semitic' incidents against Jewish communities and synagogues throughout Europe (Pardo and Peters 2010; Pardo 2015). As a result of these deeply embedded perceptions on Europe, in the eyes of many Israelis there is no distinction between antisemitism and anti-Zionism - which has long been part of the Palestinians' national and political discourse, crucial in demarcating a sharp line between racism and opposition to a political ideology (settler colonialism, among other see Hage, 2015). And for Jews, Israel is an act of national redemption and many Palestinians will agree that they should be accorded the same respect as any other national/ethnic group (interviews carried out by one of the authors, May/June 2016. See also Khalidi, 2016).

For Palestinians, Britain's Balfour Declaration plays a huge role in their 'nakba', dispossession and loss of their homeland. As recent as July 2016, the Palestinian leader Mahmood Abbas called for Palestinians to sue the British government over the Balfour declaration of November 1917 (Black,2016). In the eyes of many Palestinians the UN's decision to partition Palestine was an emotional response to 
the horrors of the holocaust but 'under more 'normal' circumstances, the compelling claims to sovereignty of the Palestinian majority would have prevailed.

'Western allies' reaction of guilt is understandable, but that does not mean the Palestinians should have to pay for crimes committed by others-a classic example of two wrongs not making a right" (interviews carried out with a focus group Bethlehem, May/June 2016). The feeling of victimhood and anger that this reaction fuels does not simply concern the Palestinians paying the price of the Western guilt. Reproduction of 'Palestinians' as 'Arabs' in the Israeli discourse and resistance of the 'outsider' such as 'Europeans' to understand this identity construction process (of Palestinians labelled as Arabs) has fed the feelings of injustice and victimhood. As Israeli leader, Moshe Dayan, was quoted as admitting:

We came to this country which was already populated by Arabs, and we are establishing a Hebrew, that is a Jewish, state here...Jewish villages were built in the place of Arab villages... There is not a single community in the country that did not have a former Arab population" (in Beit-Hallahmi, 1993: 114).

Many Palestinian participants who self-identify as Palestinians themselves (rather than as Arabs) acknowledge this as an archaism from the mid-20th century that Palestinians themselves resist using. 'First, and in general, surely, the term that an ethnic or national group uses to designate itself is preferable to the terms that its 'antagonists' have historically used to designate it. Secondly, and what is at stake here, is not merely rhetoric, but a form of historical distortion that makes it all but impossible for outsiders to fully grasp the nature of the conflict' (interviews carried out with a focus group Bethlehem, May/June 2016). In their eyes, their plight for their self-identification remains unaddressed performing the feeling of injustice.

The question of what kind of EU identity they wish for is therefore heavily intertwined with the agency of EU representatives and how they navigate around the various sensitivities of Israelis and Palestinians on a day-to-day basis. We observe that through emotional performativity, the ways that past and present traumatic experiences are memorialised and performed can be quite similar across our observations of EU representatives, Israeli and Palestinian officials. Although the main emotion often associated with Europeans' memory of the trauma of WWII and the holocaust is one of guilt (and shame); for Israeli Jews, fear, insecurity, uncertainty and anxiety about the present and the future; and for Palestinians, a very strong sense of injustice and victimhood, we also observe Palestinians experiencing, expressing and identifyingwith emotions of anxiety, insecurity, fear and uncertainty. Similarly, as expressed in our interview quotations earlier, EU officials also identify with emotions of uncertainty and insecurity in regard to the situation on the ground in the oPt and Israel. And Israelis often perform anger at their historical injustice and victimhood. 
Europeans and some Israeli Jews also share a similar technic of how to address the memory of trauma. This technic, already eluded to earlier is one of being speechless because pain, shame and guilt of being unable to prevent the traumatic experience. The key effect of trauma is thus a form of speechlessness. For example, in some Israeli families, youth members told one of the authors about how their parents never speak with them about the pain they and their parents had experienced during the Holocaust. When asked why this is so, they told her that most probably their parents are ashamed on behalf of their own parents that the Jews at the time 'did not do enough' to save themselves. When interviewing German EU representatives in the oPt in an unofficial capacity there is often reference to the German shame of "The mass murder of six million Jews, carried out in the name of Germany, (that) has brought indescribable suffering to the Jewish people, Europe and the entire world. We therefore try to leave it behind us and focus on positive engagements with both Israelis and Palestinians here" (interviews held at the Representative office of Germany, Ramallah, October, 2016).

Conceptually, this speechlessness is carefully explained by Hutchison (2016: 80) who, through her thorough and extensive academic and interdisciplinary literature excavation, suggests that the challenge of expressing trauma is best reflected by a common response to it: speechlessness or what she refers to as silence. In the case of one of the author's interviewees, their parents' speechlessness resonates pain which no amount of words can explain. This very speechlessness can speak louder than words: it reflects how Israelis 'struggle to free what becomes trapped by language: the emotional dimensions of one's self that have been marked, inimitably, by their experiences' (Hutchison 2016: 76-78). Fassin (2008) argues that memory of trauma becomes a political argument through which the experience of both Palestinians and Israelis as victims becomes shared (See also Fassin and Rechtman, 2009; Perugini, 2014). EU officials acknowledge this: "Jews were victims of the Holocaust, Palestinians are victims of the 'nakba', we today are victims of what our ancestors decided many decades ago ... it is all very frustrating really ... In some moments I get very depressed here. It's like being in a vicious circle" (interview with an official from an EU Member State representative office, Ramallah, October 2016). It is with emotions performed thus that this EU official constructs the EU as an often helpless actor in the status quo of this intractable conflict.

However, this helplessness is sometimes addressed through another emotional performance: enacting a compassionate EU towards the most vulnerable groups to trauma. As one Member of the European Parliament told one of the authors:

We are known as the payers in this conflict ... Since 1971 the European Community has been making financial contributions to the regular budget of the United Nations Relief and Works Agency for Palestine Refugees (UNWRA).,,We also provide assistance for recreational activities in schools and in refugee camps in the West Bank and the Gaza Strip, we target children aged six to fourteen, many of them traumatized from the ongoing conflict. We cannot ignore these children. Yet another 
generation is facing the trauma of lost homes and family members ... We also finance and help facilitate the movement of ambulances within the occupied Palestinian territories and the monitoring of the humanitarian situation, particularly in areas under closures and curfews, as well as visits to detainees and communication with their families' (interview with a Member of the European Parliament, East Jerusalem, October 2016, own emphasis).

The way that EU representatives relate their own emotions to this intractable conflict is thus to emphasize the experience of those most vulnerable - children. Through this emotional performativity that expresses the EU's being and communicates it with others, the said MEP constructs the EU's identity as an actor that cares about what really matters in this conflict: vulnerable children, through psychological support to deal with their trauma of conflict and war. Accordingly, the EU's agency is formulated as a caring "being" assisting the most vulnerable.

On another occasion, another official from the EP elaborated on this point:

From my various field visits to both Israel and the oPt, I can see that it is the subjective experience of all the children (that I met on both sides) of the objective events that they face every day that constitutes their trauma... The more they intrinsically believe that they are endangered, the more traumatized they are...Particularly in Palestinian refugee camps, the bottom line is an overwhelming emotion and a feeling of utter helplessness of these children and their close relatives. We are very concerned that this plays a leading role in the long-range effects" (interview held at the EP, Directorate-General for External Policies of the Union, Policy Department, Brussels, February 2016).

It is therefore extremely important to understand and nuance these emotional performances (see also Lucarelli and Fioramonti 2010) in order to understand the EU's agency when it comes to the Israeli-Palestinian issue. Theseemotional performances are not simply diplomatic tools of 'rational' actors with their pre-defined identity; rather, they are expressions of institutionalised feelings that express the EU's being to others, and therefore, reconstruct its identity and agency. Hence, what we want to shed light on here is on how the way in which emotions associated with memories of trauma are performed by EU officials is linked to the EU's collective identity vis-à-vis the Middle East conflict and by extension and potentially also as a global actor.

\section{Conclusion}

This article has addressed a neglected question in IR in general and EU studies in particular: what role do emotions play in the praxis of institutions and what impact do emotions have on institutional agency and identity? Focusing on the case of EU representatives' practices in the context of the prolonged Middle East conflict, it has been argued that the EU's identity and foreign policy agency has been (and continues to be) (re)constructed through its representatives' emotional performances 
which are, in turn, institutionalized within the EU's foreign policy structures. When referring to EU representatives, we have extended the analytical scope of our work from EU officials based mainly in Brussels to those who are on the ground in Israel or the oPt as the latter are directly and more emotionally faced with the day to day challenges that living in conflict zone entails. Three conclusions can be derived from this discussion:

First, while drawing upon different, and adding to existing, academic approaches to the study of emotions in politics, the article provides readers with an analytical framework to study emotions and institutions in world politics. We have made the point that emotions as performances are also about the construction of the Self's identity.

Second, our discussion here has highlighted that EU representatives' emotional performances are not 'private' but political in the sense that they are institutionalized in the EU's foreign policy structures.

Third, the analytical focus on memory of trauma (through the emotions associated with trauma as process) has facilitated a new perspective for studying the EU'sforeign policy vis- à -vis the Israeli-Palestine conflict. Emotions of mistrust, victimhood, injustice, guilt, and shame that are performed by the parties are contextualized in their memory of traumatic pasts and subjective articulations of their respective histories. We acknowledged that although not all EU member states may necessarily share the same national mythologies about historically traumatic events, these strongly influence how representatives perceive 'the Other'. This analysis has again shown that emotions are more than simply 'socio-psychological barriers' but rather techniques of expressing 'the self' to the outside world.

Our aim in this article has been to instigate a more nuanced discussion between the emotions literature in International Relations and the European Union studies literature to further understanding of the politics of emotions that increasingly constrain what kind of a global actor the EU actually is or can become. We hope that by critically engaging with both literatures and by shedding light on the specific case of the EU in the Middle East conflict we have shown that due attention needs to be given to the role that emotional performativity of EU officials plays in the EU's collective identity formation. Building on our work here, future research could explore how EU representatives' emotional performativity may or may not help in bringing about positive transformation in this intractable conflict.

\section{References}

Ahmed, S. (2004). The cultural politics of emotion. New York: Routledge. 
Alexander, J. (2004). 'Towards a Theory of Cultural Trauma' in Alexander, J. et al. Cultural Trauma and Collective Identity. Berkeley, 1-30.

Bar-Tal, D. and Halperin, E. (2011). Societal Beliefs and Emotions as SocioPsychological Barriers to Peaceful Conflict Resolution. Palestine-Israel Journal. Retrieved from http://www.pij.org/details.php?id=1535

Becker, D. J. (2014). Memory and Trauma as Elements of Identity in Foreign Policymaking in Resende, E. \& Budryte, D. Memory and Trauma in International Relations: Theories, Cases and Debates. Routledge, 57-73.

Beit-Hallahmi, B. (1993). Original Sins. Reflections on the History of Zionism and Israel. Olive Branch Press.

Bell, D. (2006). Introduction: Memory, Trauma and World Politics in Bell, D. Memory, Trauma and World Politics: Reflections on the Relationship Between Past and Present. Palgrave Macmillan, 1-32.

Bially Mattern, J. (2011). A practice theory of emotion for International Relations. In E. Adler and V. Pouliot (Eds.), International practices (pp. 63-86). Cambridge: Cambridge University Press.

Black, I. (2016). Will Palestinians sue Britain over the Balfour Declaration of 1917? The Guardian. 27 July.

Bleiker, R. \& Hoang, Y. (2006). Remembering and Forgetting the Korean War: From Trauma to Reconciliation in Bell, D. Memory, Trauma and World Politics: Reflections on the Relationship Between Past and Present. Palgrave Macmillan, 195-212.

Bleiker,R., \& Hutchison, E. (2008). Fear no more: emotions and world politics. Review of international studies, 34(1), 115-135.

Bottici, C. \& Challand, B. (2013). Imagining Europe: Myth, Memory, and Identity. Cambridge: Cambridge University Press.

Broadhead, P. \& Keown, D. (eds.) (2007). Can Faiths Make Peace? Holy Wars and the Resolution of Religious Conflicts. I. B. Tauris.

Chirot, D., Shin, G., \& Sneider, D. (eds.) (2014). Confronting Memories of World War II. European and Asian Legacies. Seattle: The University of Washington Press.

Crawford, N. C. (2000). The passion of world politics: Propositions on emotion and emotional relationships. International Security, 24(4), 116-156.

Crawford, N. C. (2014). Institutionalizing passion in world politics: fear and empathy. International Theory, 6(03), 535-557.

Demertzis, N. (ed.) (2013). Emotions in Politics. The Affect Dimension in Political Tension. Palgrave. 
Edkins, J. (2003). Trauma and the Memory of Politics. Cambridge: Cambridge University Press.

Edkins, J. (2006). Remembering Rationality: Trauma Time and Politics in Bell, D. Memory, Trauma and World Politics: Reflections on the Relationship Between Past and Present. Palgrave Macmillan, 99-115.

Entman, R. M. (2004). Projections of Power. Framing News, Public Opinion, and U.S. Foreign Policy. The University of Chicago Press.

Fassin, D. (2008). The Humanitarian Politics of Testimony: Subjectification through Trauma in the Israeli-Palestinian Conflict. Cultural Anthropology, 23(3), 531-558.

Fassin, D. \& Rechtman, R. (2009). The Empire of Trauma. An Inquiry into the condition of victimhood. Princeton University Press.

Fattah, K., \& Fierke, K. M. (2009). A clash of emotions: The politics of humiliation and political violence in the Middle East. European journal of international relations, 15(1), 67-93.

Feuchtwang, S. (2006) Memorials to Injustice in Bell, D. Memory, Trauma and World Politics: Reflections on the Relationship Between Past and Present. Palgrave Macmillan, 176-94.

Fierke, K. M. (2006). Bewitched by the Past: Social Memory, Trauma and International Relations in Bell, D. Memory, Trauma and World Politics: Reflections on the Relationship Between Past and Present. Palgrave Macmillan, 116-34.

Fierke, K.M. (2009). Agents of death: the structural logic of suicide terrorism and martyrdom. International Theory, 1(01), 155-184.

Hage, G. (2015). Alter-politics: Critical anthropology and the radical imagination. Melbourne: Melbourne University Publishing.

Innes A.J. \& Steele, B. J. (2014). Memory, Trauma and Ontological Security in Resende, E. \& Budryte, D. Memory and Trauma in International Relations: Theories, Cases and Debates. Routledge, 15-29.

Hall, T. H. (2015). Emotional Diplomacy: Official Emotion on the International Stage. Cornell University Press.

Herman, Judith, L. (2015) Trauma and Recovery: The Aftermath of Violence--From Domestic Abuse to Political Terror, Basic Books, 1R edition.

Halperin, E., \& Pliskin, R. (2015). Emotions and emotion regulation in intractable conflict: Studying emotional processes within a unique context. Political Psychology, 36(S1), 119-150. 
Hutchison, E. (2016). Affective Communities in World Politics. Cambridge: Cambridge University Press.

Hutchison, E., \& Bleiker, R. (2014). Theorizing emotions in world politics. International Theory, 6(03), 491-514.

Kattago, S. (2012). Memory and Representation in Contemporary Europe. The Persistence of the Past. London: Routledge.

Khalidi, A. S. (2016). As Palestinians mourn their Nakba, the UK must acknowledge its responsibility. The Guardian, 15 May.

Kinnvall, C. (2002). Nationalism, religion and the search for chosen traumas Comparing Sikh and Hindu identity constructions. Ethnicities, 2(1), 79-106.

Lucarelli, S. \& Fioramonti, L. (eds.) (2010). External Perceptions of the European Union as a Global Actor. London: Routledge.

Lynggard, Kennet (2016) 'Exploring the emotional appeal of green and social Europe myths among pan-European Union Organizations,' Journal of European Public Policy, published online 28 September.

Manners, I. \& Whitman, R. (1998). Towards identifying the international identity of the European Union: A framework for analysis of the EU's network of relationships. Journal of European Integration, 21(3), 231-249.

Manners, I. \& Whitman, R. (2003). The 'difference engine': constructing and representing the international identity of the European Union. Journal of European Public Policy, 10(3), 380-404.

Mercer, J.(1997). Reputation and rational deterrence theory. Security Studies, 7(1), 100-113.

Mercer, J. (2006). Human nature and the first image: emotion in international politics. Journal of International Relations and Development, 9(3), 288-303.

Mercer, J. (2010). Emotional beliefs. International organization, 64(1), 1-31.

Meskell, L. (2006). Trauma Culture: Remembering and Forgetting in the New South Africa in Bell, D. Memory, Trauma and World Politics: Reflections on the Relationship Between Past and Present. Palgrave Macmillan, 157-75.

Moisi, D. (2007). The clash of emotions: Fear, humiliation, hope, and the new world order. Foreign Affairs, 8-12.

Moisi, D. (2010). The geopolitics of emotion: How cultures of fear, humiliation, and hope are reshaping the world. Anchor. 
Newman, D. \& Yacobi, H. (2008). The EU and the Israel-Palestine conflict in Diez, T. et al. The European Union and Border Conflicts. The Power of Integration and Association. Cambridge University Press, 173-202.

Pain, R. (2009). Globalized fear? Towards an emotional geopolitics. Progress in Human Geography, 33(4), 466-486.

Pardo, S. (2015). Normative Power Europe Meets Israel. Perceptions and Realities. Lexington Books.

Pardo, S. \& Peters, J. (2010). Uneasy Neighbours: Israel and the European Union. Lexington Books.

Perugini, N. (2014). The Moral Economy of Settler Colonialism: Israel and the "Evacuation Trauma". History of the Present, 4(1), 49-74.

Ray, L. (2006). Mourning, Melancholia and Violence in Bell, D. Memory, Trauma and World Politics: Reflections on the Relationship Between Past and Present. Palgrave Macmillan, 135-56.

Resende, E. \& Budryte, D. (2014) Introduction in Resende, E. \& Budryte, D. Memory and Trauma in International Relations: Theories, Cases and Debates. Routledge, 112.

Ross, A. A. (2006). Coming in from the Cold: Constructivism and Emotions. European Journal of International Relations, 12(2), 197-222.

Ross, L., \& Ward, A. (1995). Psychological barriers to dispute resolution. Advances in experimental social psychology, 27, 255-304.

Saeidi S. and Turcotte H.M. (2011). Politicizing Emotions: Historicizing Affective Exchange and Feminist Gatherings. International Studies Review, 13(4), 7-9.

Sasley, B. E. (2011). Theorizing States' Emotions. International Studies Review, 13(3), 452-476.

Sasley, B. E. (2014). Remembering and Forgetting in Turkish Identity and Policymaking in Resende, E. \& Budryte, D. Memory and Trauma in International Relations: Theories, Cases and Debates. Routledge, 138-52.

Schilling, C. L. (2015). Emotional State Theory: Friendship and Fear in Israeli Foreign Policy. Lanham: Lexington Books.

Sjöstedt, G. (1977). The External Role of the European Community. Farnborough, Hants: Saxon House.

Winter, J. (2006). Notes on the Memory Boom: War, Remembrance and the Uses of the Past in Bell, D. Memory, Trauma and World Politics: Reflections on the Relationship Between Past and Present. Palgrave Macmillan, 54-73. 
Wibben, A. T. (2010). Feminist security studies: A narrative approach. Routledge.

Zehfuss, M. (2007). Wounds of memory: The politics of war in Germany. Cambridge University Press.

[i] The role of emotions in conflicts and conflict resolution processes have been studied in the Israeli-Palestinian prolonged conflict (among others, Halperin and Pliskin, 2015). The aforementioned literature studies emotions as 'variables' between reified or fixed societal identities, not how emotions work in the construction of 'the self', of dichotomist identities, and how emotions as 'performances' challenge such identities.

[ii] Available at: http://www.timesofisrael.com/eu-envoy-comparing-labeling-toholocaust-cheapens-memoryl (Accessed 19.01.2017) 